\title{
Red Blood Cell Folate Measurement
}

National Cancer Institute

\section{Source}

National Cancer Institute. Red Blood Cell Folate Measurement. NCI Thesaurus. Code C123334.

The determination of the concentration of folic acid present in a sample of red blood cells. 